Anna Margaréta Lačoková

Univerzita v Novom Sade

Filozofická fakulta

Oddelenie slovakistiky

anna.margareta.lacok@ff.uns.ac.rs
УДК 811.162.4'373.7:811.163.41'373.7

https://doi.org/10.18485/slavistika.2020.24.2.14

оригинални научни рад

примљено 18.08.2020.

прихваћено за штампу 18.09.2020.

\title{
LEXIKÁLNE ZLOŽENIE A MOTIVÁCIA BIBLICKÝCH FRAZÉM
}

(na príklade slovenskej a srbskej biblickej frazeológie)*

V príspevku si na príklade biblickej frazeológie slovenského a srbského jazyka všímame lexikálne zloženie biblických frazém. Na základe charakteristickej lexémy, ktorá je obsahom týchto frazém, ponúkame niekol'ko kategórií, do ktorých ich z tohto aspektu možno rozvrhnút' a v rámci nich sa zmieňujeme aj o motivácii a sémantike daných frazém. Do osobitnej kategórie zarad’ujeme frazémy, ktoré sa v Biblii nachádzajú, no nie sú ňou motivované a vo svojom zložení neobsahujú biblický, ani náboženský prvok.

Klúčové slová: frazeológia, biblická frazeológia, lexikálne zloženie frazém, slovenský jazyk, srbský jazyk.

This paper focuses on the lexical composition of biblical phrasemes documented with the examples of Serbian and Slovak biblical phraseology. From this aspect, there are several categories that unite the phrasemes that have a characteristic lexeme in their composition, and they are motivated by various imagery and have various meanings. A separate category are the phrasemes that are found in the Bible but are not motivated by it and do not include either a biblical or a religious component.

Keywords: phraseology, biblical phraseology, lexical composition of phrasemes, Slovak language, Serbian language.

1. Biblické frazémy sú definované ako jazykové jednotky späté s Bibliou, ktoré sa vyznačujú sémantickou ucelenost'ou, reprodukovatel'nost'ou, preneseným významom, expresívnost'ou a knižnost'ou (Лилич et al. 1993). Ked’že sa tieto vlastnosti vzt’ahujú aj na frazémy všeobecne, ako jedna z najdôležitejších charakteristík biblických frazém sa vyzdvihuje práve ich spätost' s prameňom (Stěpanova 2004: 108).

Pri skúmaní biblickej frazeológie sa však nestačí sústredit’ iba na jednotky, ktoré vo svojom zložení majú biblický prvok. V príspevku sa preto zameriavame práve na rôznorodé lexikálne zloženie tohto súboru. Naším ciel’om je na základe slovenských a srbských biblických frazém poukázat' na túto skutočnost', ponúknut' niekol'ko kategórií, do ktorých ich možno z tohto aspektu rozvrhnút' a v rámci

* Príspevok je parciálnym výsledkom projektu Diskurzy menšinových jazykov, literatúr a kultúr v juhovýchodnej a strednej Európe (č. 178017), ktorý financuje Ministerstvo osvety, vedy a technologického rozvoja Republiky Srbsko; Príspevok predstavuje čast' výskumu realizovaného pre potreby dizertačnej práce Biblická frazeológia $v$ slovenskom a srbskom jazyku na doktorandskom štúdiu jazyka a literatúry Filozofickej fakulty Univerzity v Novom Sade pod vedením školitel'ky doc. Dr. Jasny Uhlárikovej. 
nich na základe vybraných príkladov ${ }^{1}$ poukázat' aj na motiváciu a sémantiku tejto skupiny frazém.

Analyzovanú vzorku, biblické frazémy a parémie, sme vyexcerpovali z frazeologických a lexikografických slovníkov, z monografií slovenského a srbského jazyka, ako aj z ostatných jazykových príručiek konzultujúc pritom kontrolné korpusy. Úhrnne bolo analyzovaných 1193 slovenských a 1285 srbských frazém, spolu 2478 frazém. S ciel'om zachovat' vyhovujúcu prehl'adnost' zdroj neuvádzame za každou jednotkou, ktorou v príspevku ilustrujeme naše zistenia, ale v ich úplnom zozname na konci práce.

2. Existujú mnohé spôsoby typologizácie biblických frazém (Skladaná 2003; Stěpanova 2004; Baláková a i. 2016; Ferencová 2006; Markovičová 2013 atd’.), ktoré umožňujú ich analýzu z rôznych aspektov. Jeden zo spôsobov skúmania tohto súboru frazém je aj analýza ich lexikálneho zloženia.

Detailnou analýzou slovenských a srbských frazém sme prišli k uzáveru, že z aspektu lexikálneho zloženia možno dané jednotky rozvrhnút' do niekol'kých kategórií:

1. Frazémy, ktorých súčast’ou je lexéma pomenúvajúca dobro (Boh/Бoz; Kristus/

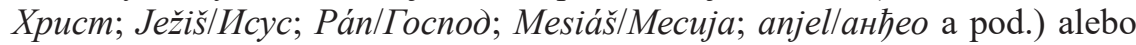
zlo (satan, diabol/Ђаво, Ђавао; čert/враг, бес; antikrist/Aнтихрист a pod.),

2. frazémy, ktorých súčast’ou je lexéma označujúca základné krest’anské princípy (duch/дyx; duša/dyma; srdce/cpue; viera/вера; пеbo/небо; raj/paj; hriech/ гpex a pod.),

3. frazémy, ktorých súčast'ou je lexéma označujúca krest’anské praktiky (krst/ критење; kázeň/nроповеd; pokánie/кајање; оbet'/жртва; modlitbal молитва; Otčenáš/Оченаш; еvanjelium/јеванђеље a pod.),

4. frazémy, ktorých súčast'ou je biblická osobnost', resp. biblické antroponymum alebo biblické mesto, resp. iné biblické toponymum,

5. frazémy motivované biblickým príbehom, ktorých súčastou sú lexémy náboženského a svetského charakteru.

Uvedené kategórie zjednocujú frazémy, ktoré vo svojom zložení majú jednu charakteristickú lexému, pričom sú motivované rôznymi obrazmi a majú rozličné významy. Ako osobitnú kategóriu vyčleňujeme frazémy, ktorých súčast’ou nie je biblický, ani náboženský prvok. Je to skupina frazém, ktoré nie sú motivané Písmom svätým, no predsa sa v ňom ako ustálené jazykové jednotky nachádzajú.

V pokračovaní sa zmienime o motivácii a sémantike jednotiek zaradených do daných kategórií.

${ }^{1}$ Tvrdenia ilustrujeme slovenskými a srbskými biblickými frazémami. V prípade, ked' uvedený príklad nemá svoj sémantický ekvivalent v druhom skúmanom jazyku, uvádzame len slovenský alebo len srbský príklad. Potrebné je poznamenat', že sa zistenie o existovaní sémantického ekvivalentu v druhom skúmanom jazyku získané počas analýzy danej problematiky nemusí zhodovat's reálnou situáciou, ked’že zaradenie určitých jednotiek do slovníkov a monografií v najväčšej miere závisí od autorov a zostavovatel’ov daných jazykových príručiek. Naším ciel’om bolo zoskupit' a analyzovat' čo najväčší počet biblických frazeologických jednotiek používajúc dostupné relevantné slovníky a monografie. 
2.1.1. Motivačnou bázou frazém, ktoré pomenúvajú dobro a vo svojom zložení obsahujú lexémy Boh/Бoz; Kristus/Xpucm; Ježiš/Иcyc; Pán/Гocnod; Mesiáš/Mecuja a pod., sú biblické obrazy a chápanie Boha a jeho vlastností. Prejavuje sa v nich ako stvoritel' (Ani Pán Boh svet naraz nestvoril / Бог jе најпре створио шуму nа човека), ako niekto, kto má zvrchovanost', silu (Сам (само) Бог нема господара), čia moc a nadvláda sa uznáva (To je v Božích rukách / To (све) је у Божијим рукама) a čia vôl'a sa prijíma (Nech sa stane vôl’a Božia / Kaо што је Богу воља). Do Bоžej milosti a pod Božiu ochranu a starostlivost' sa porúča (s poтосои Božou / Уз Божијy nомоћ!). Boh sa zároveň chápe ako niekto, kto pomáha chudobným (Kde je bieda najväčšia, ротос Boha najbližšia / Где је највећа нужда, онда је и неизбежна помоћ Божија) a je štedrý darca, dokonca aj darca života a zdravia (Nech ti dá Pán Boh zdravie! / <Дај> Боже здравља). Je stelesnením lásky, pokoja, krásy, dobroty, úprimnosti, spravodlivosti, ospravedlnenia, odpúšt’ania, múdrosti a bezhriešnosti (Kde je viera v Boha, tam je dar múdrosti, kde nevera v Boha, tam je tma hlúpos$t i$; Где нема науке, ту ни Бога међу тим људима нема). Je vševedúci a vševidiaci (Boh <sám> vie / Бог <свети (један, једини, сам)> зна (не зна) <кад, како>) а jeho autorita sa konfrontuje aj s l'udskými autoritami (Čo Bohu, Bohu, a čo svetu, svetи / <дати> иару ияарево, $<a>$ Богу Божије <ваља давати >).

V každodennom živote sa človek odvoláva na Božiu prítomnost' a jeho zasahovanie do l'udského života sa môže sledovat' v zmysle spájania l'udí, usmerňovania, ochrany, poznačovania, zasahovania prostredníctvom poslov a pod. (Sám pánboh t'a sem poslal (Nebesá t’a sem poslali) / Ко да га је сам Бог послао; Boh mi <je> svedok (svedkom) / Бог ми је сведок!)

Vo vzt’ahu človeka voči Bohu sa prejavuje vd'aka, ale aj jeho akceptovanie alebo neakceptovanie vo všeobecnosti (mat' (nemat') Boha pri sebe; измирити се с Богом; spúštat'sa Boha). V zaklínaniach sa upozorn̆uje na trest nezrealizovaného priameho kontaktu s Bohom (Лица Божијег никад не угледао!).

Na základe uvedeného možno uzavriet', že sa l'udské chápanie Božích vlastností vo frazeológii, tak v slovenskej, ako aj v srbskej, zhoduje s teologickými zásadami uvedenými v Biblii, resp. biblické obrazy a chápanie Boha sú motivačným základom daných frazém. Boh sa tak v skúmaných frazémach prejavuje ako stvoritel', jeho moc je zvrchovaná a bez obmeny, kontroluje človeka a vplýva na jeho činy, chráni a stará sa oňho, je darca života a zdravia. S ním sa spájajú pozitívne vlastnosti, city a stavy človeka ako sú láska, pokoj, dobrota, krása, úprimnost' a i., ale ked’že je aj spravodlivý a súdi priestupky, vzbudzuje bázeň.

Frazémy, ktoré vo svojom zložení obsahujú lexému anjel/arheo sú najčastejšie motivované vlastnost'ami týchto nadprirodzených bytostí. V slovenskej a srbskej biblickej frazeológii sa anjeli prejavujú ako bytosti, ktoré zasahujú do života l'udí a pozdravujú ich. Sú dobrí, nevinní, trpezliví, krásni, ochraňujú človeka $(J e<d o b r y ́>$ ako anjel; čistý (nevinný, pekný, krásny) ako anjel / чист (добар) као анђео; anjel strážny (strážca, ochranca) / анђео чувар (стражсанин); анђео хранитељь (хранилаи) atd'.). Primárne sú však prítomní mimo života l'udí, čiže v inej dimenzii, ked’že sa človek v ich prítomnosti ocitá až po svojej smrti (odíst' medzi anjelov). Podobu anjela, ktorý symbolizuje dobro, niekedy má aj zlo, čím sa zdôrazňuje falošnost' a pretvárka, resp. pokrytectvo l'udí (anjel z rožkami (rožky) / Анђео у лииy, Ђаво у сриy). 
2.1.2. Skupina frazém, ktorých súčast'ou je lexéma pomenúvajúca zlo (satan, diabol/ђаво, Ђавао; сеert/враг, бес; antikrist/Aнтихрист а i.), je motivovaná biblickými obrazmi týchto temných bytostí. Pomenúvajú zlého a nerozvážneho (z pekla vyšibaný (vyhnaný); Lucifer z pekla; čertu dobrý; Zapísal dušu čertovi / Предаде (nродао) душу Ђаволу; Он је Антихрист), nahnevaného (Akoby ho bol diabol posadol; Akoby bol $<$ sám> diabol doň vošiel (vstúpil) / Као да је Ђаво ушао у њега), ale aj prefíkaného (Čertom z pekla ušiel) a rýchleho človeka (Beži (uteká), ani čo by ho všetci čerti hnali / Бежи као да га (их) јуре сви бесови (Ђаволи)). Pomenúva sa nimi aj nebezpečenstvo (Čert <nikdy> nespí / Bраг (Ђаво) не спава <yduљ>; Ђаво не мируje), riskovanie (pokúšat' osud (št'astie, Boha, diabla, čerta)) a skrotenie niekoho (vyhnat' (vyháňat') diabla (čerta) [z niekoho] / истерати ђавла (Ђавола, врага) [из некога]).

Skúsenost' l'udí zhrnutá vo frazeológii poukazuje na to, že zlé sily sú mocné, stále prítomné a ich silu netreba podceňovat' (Добар је Бог, али су и Ђаволи јаки). Ich prítomnost' v živote človeka nie je želaná a odmieta sa (Иди, Ђаволе, од мене и од моје душе!).

2.2. Frazémy, ktoré vo svojom zložení obsahujú lexémy pomenúvajúce základné krest’anské princípy (duch/дyx; duša/дyua; srdce/cpųe; viera/вера; nеbo/небо; raj/ paj; hriech/гpex a pod.), sú najčastejšie motivované človekom, jeho vlastnost'ami, správaním sa a činnost'ami.

Frazémy obsahujúce lexémy $d u c h / \partial y x$, duša/dyua, srdce/cpụe súvisia s intenzitou vykonávania určitej činnosti, pričom najčastejšie ide o maximálnu intenzitu: celým srdcom; celou dušou / свим срием; свом (читавом, ичелом, пуном) душом. Reprezentujú človeka a jeho správanie sa, poukazujú na jeho podstatu, city a vlastnosti: úprimnost' a dôveru (otvorit' $<$ si $>$ srdce (dušu) <dokorán $>$ / omвopumu (отварати, открити, излити) душу <и сриее>), zármutok, trápenie (Je mu t’ažko na srdci (pri srdci, okolo srdca) / На души (при души, у души) му је (им је) лако (ласно, ведро, тешко)), úl'avu (Ul'avilo sa ти (odl'ahlo mu) па duši / Одлакну (лакну, одлакнуће, лакнуће) ми (јој) на души) а pod.

Najčastejšie zobrazujú pozitívne l’udské vlastnosti, city a psychofyzické stavy človeka: spokojnost' (mat' dušu na mieste (na pokoji) / Cpu̧e ми је на месmy), dobro, vernost', šl'achetnost' (mat' mäkké (zlaté, verné, šl'achetné) srdce / бити доброг (меког) срияа; златно сри̧е), l'udskost', správne hodnoty (mat'srdce na pravom mieste / Срије му (ми, ти) је на мери), ale aj bezcitnost' (mat' tvrdé (kamenné) srdce / камена (каменог, тврда, тврдог) срияа <бити>), nečestnost' (predat' (zapredat') svoju dušu / продати душу <нечастивом (Ђаволу, врагу)>), obmedzenost' (chudobnýv duchu (duchom, na duchu, na duši / сиромаман (сиромах, инокосан, ничти, ниччи) духом).

Frazémy obsahujúce lexému viera/вера upozorňujú na dôležitost' skutkov (Viera bez skutkov je mŕtva / Вера без дела мртва je), kým tie, ktoré majú vo svojom zložení lexému пеbo/небо na blahobyt a príjemnost' (raj na zеті / рај на земљи; то је rajská (nebeská) hudba).

Frazémy s lexémou hriech/2pex pomenúvajú vel'ký priestupok (donebavolajúci hriech / вапијући грех на небо (у небо, до неба)) a upozorňujú aj na následky hriechu (Jeden hriech plodi druhý / Грех је греху заметак). 
2.3. Frazémy, ktorých súčast’ou je lexéma označujúca krest’anské praktiky ( $k r s t)$

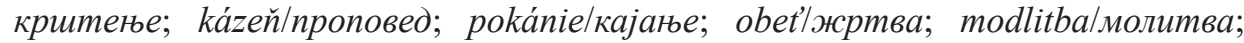
Otčenáš/Оченаш; evanjelum/јеванђеље a pod.), najčastejšie súvisia s medzil'udskými vzt'ahmi.

Kázeň ako náboženská, mravoučná a poučná reč prednesená obyčajne na kazatel'nici pri bohoslužbách má v analyzovaných biblických frazémach význam napomínania, hrešenia niekoho (mat' (čítat', držat', robit') [niekomu] kázeň (kázne) / ouumamu проповед [некоме]), pričom sa v srbskom jazyku rovnaký význam dosahuje aj lexémои Оченаш: очитати (очатити) [некоме] Оченаш (Оченаш). Lexéma pomenúvajúca Modlitbu Pána Otčenáš/Оченаu však vo frazémach oboch jazykov pomenúva schopnost' vediet' niečo vel'mi dobre, naspamät': vediet' [niečo] ako otčenáš / знати (говорити, изговорити, учити, научити) [нешто] као Оченаш. Pozoruhodná je aj frazéma verit' [niečomu (niekomu)] ako evanjeliu / Bepyje y то као да је записано y Јеванђељу, kde sa v oboch jazykoch lexéma evanjelium/jеванђеље chápe ako niečo, čomu sa dôveruje.

2.4.1. Najčastejšími motivantmi skupiny frazém, ktorých súčast'ou je biblická osobnost', sú Adam a Eva, prví l'udia, ktorí v Rajskej záhrade zhrešili, boli z nej vyhnaní a na ten spôsob podl'a Biblie ovplyvnili osud celého l'udstva. V tom zmysle sa aj očakáva, že vo frazeológii budú figurovat' v rámci viacerých obrazov. V skúmaných frazémach sa tieto osobnosti vnímajú v kontexte nadčasovej kategórie, resp. ako niekto, v čej prítomnosti sa človek ocitá po smrti (kopat' loj s Adamom), ale vzhl'adom na svoju pozíciu na začiatku sveta, aj ako niekto prítomný od začiatku (začat' (začinat') od Adama <a Evy> / од Адама развести (почети); од Адама <u Еве> (од Еве и Адама)), resp. starý (Адамов век). Zároveň sú symbolom l'udí vo všeobecnosti, často vnímaní ako prarodičia celého l'udstva (Evine dcéry (deti) / Eвин син; Евина кћи (Евине кћери, кћери Еве)). V kontexte biblického obrazu pokušenia a pádu prvých l'udí Adam a Eva súvisia aj s nahotou (<byt $><$ odetá $>v$ Evinom rúchu; $<$ byt'> <oblečený> v Adamovom rúchu (šatách) / y Евином костиму; у Адамовом (Адамову) костиму) a pokušením (Evino jablko / Евина (златна, рајска) јабука (патлицан)).

Obrazy vysokého veku a staroby súvisia aj so starozákonnými osobnost’ami ako sú Matuzalem a Abrahám (<byt’> starý ako Matuzalem (ako Abrahám, ako svet) / cmap као Метузалем). Abrahám, podobne ako Adam, je ten, v čej prítomnosti sa človek ocitá po svojej smrti (Už je v lone Abrahámovom (dostat'sa do lona Abrahámovho) / отићи (преселити се, бити примљен) у Аврамово (Абрахамово) крило).

Biblické osobnosti v skúmaných frazémach zobrazujú aj d’alšie l'udské vlastnosti: vel'mi chlpatý človek je ako Ezau (chlpatý ako Ezau), zvodná žena je ako putifarka (putifarka), mocný človek sa prirovnáva k biblickému silákovi Samsonovi (<mocný ako> Samson), múdry sa dáva do kontextu s biblickým král’om Šalamúnom (múdry ako Šalamún / мудар (паметан) као Соломон), pyšná žena pripomína královnú zo Sáby (chodit' (niest' sa) ako král'ovná zo Sáby) atd'. Falošnost' pripomína zradu učeníka Judáša pred ukrižovaním Ježiša Krista (predat' (zapredat') [niekoho (niečo)] za judášsky groš / за jyдин грош продати (продаватu); judášsky bozk / Jyдин пољубаи), pochybovačnost' učeníka Tomáša (neveriaci Tomáš (tomáš) / неверни (невјерни, неверован, неверовани, невјеровани, невјероватни) Тома (Томо, Томаи)), кým 
bystrost' a dôvtip evokuje Ježišovho učeníka Filipa (mat' (nemat') Filipa). Symbolika milosrdného Samaritána sa každodenne používa na označenie dobrého človeka, ktorý nezištne pomáha inému (<milosrdný> samaritán (Samaritán); милостиви Самарјанин (добри Самарићанин)).

Biblické obrazy sa prejavujú aj v rámci každodenných medzil’udských vzt’ahov. Benjamín tak symbolizuje najmladšieho člena rodiny alebo istého spoločenstva ( $b y t^{\prime}$ benjaminom (benjaminkom) <rodiny>), kým Dávid a Goliáš nerovných súperov (Dávid a Goliáš (súboj Dávida s Goliášom) / <Носе се ко> Давид и Голијат). Nachádzame ich však aj v kontextoch každodenných situácií: obchádzat' l'udí a nedosiahnut' želaný výsledok l'ud’om pripomínalo biblickú osobnost' Pavla (Šavla) (chodit’ od Šavla k Pavlovi), kým neočakávané situácie pripomínajú Baláma a jeho oslicu, ktorá na ceste za moábskymi kniežatmi prehovorila (Balámova oslica). V každodenných situáciách sú biblické osobnosti používané aj v zahrešeniach: Na kieho Árona!

Určité postavy neboli frazeologizované v oboch jazykoch. Kontrastívnou analýzou uvedených slovenských a srbských biblických frazém sme si všimli, že v srbskom jazyku proces frazeologizácie nezachytil napr. starozákonného Jóba (Kniha Jób), bez ohl'adu na jeho symboliku vel'kého trápenia. Slovenský frazeologický fond obsahuje niekol'ko frazém, ktoré sú ním motivované: trpi ako Jób; Jóbove rany; Jóbova trpezlivost'; Jóbova (jóbovská) zvest' (správa), pokým v srbskom jazyku sa táto osobnost' nefrazeologizovala.

2.4.2. V zložení analyzovaného súboru frazém sa vyskytujú aj biblické toponymá.

Babylon je v biblickom kontexte mesto, kde Boh trestajúc l'udské výčiny zmiatol reč celému svetu. S týmto súvisia aj biblické frazémy zobrazujúce nedorozumenie (вавилонски језик), zmätok, chaos, neporiadok (babylonský zmätok) a ilúzie (зидати вавилонске куле).

Sodoma a Gomora sú podla Biblie miestom nerestí a hriechu. Práve tento obraz starozákonných miest sa aj frazeologizoval, tak v slovenskej, ako aj v srbskej frazeológii (<hotová> Sodoma (sodoma) $<a>$ Gomora (gomora) / Содома (Содом) $u$ Гомора (Гомор)).

Biblický príbeh o Egypte a utláčaní Izraelcov sa do frazeológie preniesol v obraze desiatich rán, ktoré z dôvodu neposlušnosti Božieho nariadenia zasiahli egyptský národ a faraóna a spôsobili im vel'ké utrpenie (egyptská rana (rany); desat' (sedem) egyptských rán).

Frazeologizáciu biblického príbehu, ktorý opisuje pád mesta Jericho, tiež nachádzame vo frazeologickom fonde slovenského a srbského jazyka. Podl'a Božieho rozkazu Izraelci okolo Jericha obchádzali šest' dní, každý deň raz. Na siedmy deň mesto obišli sedemkrát. Pri siedmom raze kňazi zatrúbili na trúbach a rohoch, lud vykríkol vel'kým bojovým pokrikom a zrútili sa mestské hradby. Frazeologizoval sa práve obraz jerichovských trúb, avšak s negatívnou konotáciou - ako nadávka hlúpemu človeku (jerichovská (Jerichova) trúba / јерихонска труба). Môžeme len predpokladat', že to súvisí s nadprirodzeným, resp. nereálnym spôsobom pádu mesta Jericho a že rozprávanie o danej udalosti u l'udí mohlo vzbudit' až takú nedôveru, že daného človeka považovali za hlupáka. 
2.5. Frazémy motivované biblickým príbehom, ktorých súčast'ou sú lexémy náboženského a svetského charakteru, najčastejšie motivovali dobré a zlé l'udské vlastnosti, ktoré v daných biblických príbehoch prichádzajú do popredia, ale aj ich charakteristický spôsob života, životné okolnosti a situácie (Шест дана не ради, а седмог се одмара; stavat'<dom> na piesku / градити (зидати) <куле> на песку; oddelit' (rozoznat') kúkol' od pšenice; triedit' (oddelit') zrno od pliev (plevy od zrna) / одвојити (одвајати, оделити) кукољ од пиенице (жита, доброг зрна); оплевити кукољ из жита; одвајати жито од кукољь; predat' (zapredat', zradit') [niekoho] za 30 (tridsat', trinást') strieborných / продати [некога] за тридесет сребрњака).

Najčastejšie sú obrazy súvisiace s ukrižovaním Ježiša Krista, ktorý je opodstatnene najsilnejším motívom a obrazom v tejto kategórii. V rámci neho si v oboch jazykoch všímame frazeologické obrazy, ktoré súvisia s Judášovu zradu (predat' (zapredat', zradit') [niekoho] za 30 (tridsat', trinást') strieborných / продати [некога] за тридесет сребрњака), vel'kým utrpením (kalich utrpenia / горка (жучна) чаша), zdĺhavým vyriešením situácie (posielat' [niekoho] (chodit') od Pontia k Pilátovi (od Kaifáša k Annášovi) / <слати [некога] (ићи)> од Понтија до Пилата), odsúdením (pribit' [niekoho] na kríž / paзапетu (разапињати, расnетu, распињати, прибити, прибијати) [некога] на крст) a pod. Priamo s tým súvisia aj frazeologické obrazy o vzkriesení Ježiša Krista, ktorých je však viac v srbskom ako v slovenskom jazyku (дићи (дигнути, дизати) [некога] из (од) мртвих; <изгледа> као да се вратио из мртвих (као да се из гроба дигао); Није трећу ноћ дочуван).

Kontrastívnou analýzou sme si všimli, že sa niektoré biblické príbehy nefrazeologizovali v oboch skúmaných jazykoch. Zaujal nás príklad motivovaný podobenstvom o múdrom a bláznivom stavitel'ovi (Evanjelium podl'a Matúša 7, 24-27), resp. symbolikou dvoch l'udí, z ktorých jeden svoj dom staval na skale, kým druhý na piesku. V slovenskom jazyku sú frazeologizované príklady oboch stavitel'ov: stavat' $<$ dom $>$ na piesku a stavat'<dom> na skale, kým v srbskom jazyku sa frazeologizoval iba príklad bláznivého stavitel'a: градити (зидати) <куле> на песку. Srbský frazeologický fond neobsahuje ani obraz „desiatich spravodlivých“ z príbehu o Sodome a Gomore, ktorí mohli zachránit toto mesto pred skazou (desat'spravodlivých), ani príbeh o zlatom tel'ati, v zmysle neopodstatného zbožňovania materiálnych vecí ( $h l$ 'adiet' [na niekoho] ako na modlu, vzhliadat' [k niekomu] ako $k$ modle). V slovenskom jazyku sa napr. nefrazeologizoval príbeh o vodách v Meríbe, v rámci ktorého sa $\mathrm{v}$ srbskom jazyku upozorňuje na lenivého človeka (Чека да из камена потече вода), príbeh o Rút, kde sa v srbskom jazyku poukazuje na zbytočnú prácu (купити класjе по старом стрништу), podobne ani obraz nasýtenia pät'tisíc l'udí pomocou piatich chlebov a dvoch rýb (Не можеш нахранити цуео свет са два хлеба и пет риба).

Niektoré príbehy sú frazeologizované v oboch jazykoch, avšak nie je frazeologizovaný ten istý obraz. Kým v slovenskej frazeológii stvorenie sveta poukazuje na začiatok (od stvorenia sveta) a na človeka ako korunu tvorstva (koruna tvorstva (všetkého)), v srbskej sa zdôrazňuje proces tvorenia, resp. ironizuje sa šest' dní tvorenia a siedmy deň oddychu v zmysle l'udskej lenivosti (Шест дана не ради, а седмог се одмара). V srbskej frazeológii potopa nepoukazuje na neporiadok, chaos a zdlíhavé rozprávanie, resp. rozprávanie od začiatku, čo nachádzame v slovenskom frazeologickom fonde (<hotová $>$ potopa $<$ sveta $>$; <začat' (rozprávat') $>$ od potopy sveta). V oboch však potopa poukazuje na d'alekú minulost' (predpotopný; To bolo ešte pred 
potopou / npe nomona; То је било још пре Потопа), nezáujem o budúcnost' (Po nás $<$ nech príde> potopa / После мене noтоп) a pod.

2.6. V skupine frazém, ktorých súčastou nie je biblický, ani náboženský prvok, ide o jednotky, ktoré nie sú motivované Písmom svätým, ale sa v ňom ako ustálené jazykové jednotky nachádzajú. Sú to jednotky zobrazujúce spôsob života, životné okolnosti a situácie, medzil'udské vzt’ahy, ako aj city a stavy jednotlivca (nevidiet' (umierat') od hladu / умирати (умрети, скапавати) од глади; ist' (byt') na úžitok / ићи (иде, иило је) у корист (у прилог, у рачун) [коме]; byt'na dne / бити на дну) 2 .

3. Na základe uvedeného uzavierame, že biblická frazeológia predstavuje rozmanitý súbor jednotiek, o čom svedčia aj uvedené príklady slovenských a srbských frazeologických jednotiek, ktoré sú motivované rôznymi obrazmi a majú rozličné významy. Rozlišuje sa aj ich lexikálne zloženie, pričom neobsahujú vždy lexému biblického, ani náboženského charakteru. Dôležité je preto opierat' sa o ich primárny zdroj, Bibliu, a o možnost' dokumentovania týchto jednotiek biblickým textom.

\section{Citovaná literatúra}

Baláková, Dana, Валерий B. Мокиенко. „Nič nie je nové pod slnkom“. Slavistična revija 64/2016, 2, 2016: 113-124.

Ferencová, Martina. „Krest’anské a biblické frazémy a ich miesto vo vyučovacom procese“. [In:] L'. Sičáková, L'. Liptáková (eds.) Slovo o slove. Prešov: Prešovská univerzita, 2006, 90-97.

Lačoková, Anna Margaréta. „Rôznorodost' biblizmov a problém vymedzenia tejto skupiny frazém (na príklade slovenskej a srbskej biblickej frazeológie)“. Slavistika XXIII/2 (2019), 23/2, 2019: 50-54.

Markovičová, Katarína. „Biblická frazeológia v denníku Pravda v roku 1988“. [In:] H. Walter, V. M. Mokienko, D. Baláková (eds.) Die slawische Praseologie und die Bibel. Greifswald: Ernst-Moritz-Ardnt-Universität Greifswald, 2013, 132-138.

Skladaná, Jana. „Textotvorné potencie frazeologických internacionalizmov“. Jazykový časopis 54, 1-2, 2003: 53-58.

Stěpanova, Ludmila. Česká a ruská frazeologie. Diachronní aspekty. Olomouc: Univerzita Palackého v Olomouci, 2004.

Лилич, Галина Алексеевна, Валерий Михайлович Мокиенко, Людмила Ивановна Степанова. „Библеизмы в русском, чешском и словацком литературных языках“. Вестник Санкт-Петербургского университета, 2, 1993: 51-59.

[Lilich, Galina Alekseevna, Valeriǐ Mikhă̌lovich Mokienko, Liudmila Ivanovna Stepanova. „Bibleizmy v russkom, cheshskom i slovatskom literaturnykh iazykakh“. Vestnik Sankt-Peterburgskogo universiteta, 2, 1993: 51-59]

\footnotetext{
${ }^{2} \mathrm{O}$ tejto skupine jednotiek sa viac zmieňujeme v Lačoková 2019: 50-54.
} 


\section{Zdroje}

Baláková, Dana. Dynamika súčasnej slovenskej frazeológie (fond somatických frazém). Greifswald: Universität Greifswald, 2011.

Buzássyová, Klára, Alexandra Jarošová. Slovník súčasného slovenského jazyka. A -

G. Bratislava: Veda, vydavatel'stvo Slovenskej akadémie vied, 2006.

Buzássyová, Klára, Alexandra Jarošová. Slovník súčasného slovenského jazyka. H -

L. Bratislava: Veda, vydavatel'stvo Slovenskej akadémie vied, 2011.

Habovštiaková, Katarína, Ema Krošláková. Frazeologický slovník: človek a príroda vo frazeológii. Bratislava: Veda, 1996.

Jarošová Alexandra. Slovník súčasného slovenského jazyka. M - N. Bratislava: Veda, vydavatel'stvo Slovenskej akadémie vied, 2015.

Kačala, Ján, Mária Pisárčiková. Krátky slovník slovenského jazyka. Bratislava: Veda, Vydavatel'stvo Slovenskej akadémie vied, 2003.

Miko, František. Frazeológia v škole. Bratislava: Slovenské pedagogické nakladatel'stvo, 1989.

Peciar, Štefan. Slovník slovenského jazyka I - VI. Bratislava: vydavatel'stvo Slovenskej akadémie vied, 1959-1968

Spasić, Želmira. Frazeološki rečnik srpskohrvatskog jezika (srpskohrvatsko-slovački). Novi Sad: Filozofski fakultet, Institut za južnoslovenske jezike [etc.], 1984.

Spasić, Želmira. Frazeološki rečnik slovačko-srpskohrvatski. Novi Sad: Filozofski fakultet, Institut za južnoslovenske jezike [etc.], 1989.

Балакова, Дана, Харри Вальтер, Валерий Мокиенко. Из библейской мудрости. Z biblickej múdrosti. Biblische Weisheiten. Greifswald: Ernst-Moritz-Ardnt-Universität Greifswald, 2015.

[Balakova, Dana, Xarri Val'ter, Valeriǐ Mokienko. Iz bibleǐskoĭ mudrosti. Z biblickej múdrosti. Biblische Weisheiten. Greifswald: Ernst-Moritz-Ardnt-Universität Greifswald, 2015]

Вуловић, Наташа. Српска фразеологија и религија: Лингвокултуролошка истраживања. Београд: Институт за српски језик САНУ, 2015.

[Vulović, Nataša. Srpska frazeologija i religija: Lingvokulturološka istraživanja. Beograd: Institut za srpski jezik SANU, 2015]

Николић, Мирослав (ред.) Речник српскога језика. Нови Сад: Матица српска, 2007.

[Nikolić, Miroslav (red.) Rečnik srpskoga jezika. Novi Sad: Matica srpska, 2007]

Оташевић, Ђорђе. Мали српски фразеолошки речник. Нови Сад: Прометеј, 2012.

[Otašević, Đorđe. Mali srpski frazeološki rečnik. Novi Sad: Prometej, 2012]

Стевановић, Михаило и др. (ред.) Речник српскохрватскога књижевног језика. Нови Сад: Матица српска, 1990.

[Stevanović, Mihailo i dr. (red.) Rečnik srpskohrvatskoga književnog jezika. Novi Sad: Matica srpska, 1990]

Стијовић, Рада и др. (ред.) Речник српскохрватског књижевног и народног језика, књига I-XIX. Београд: САНУ, 1959-2014.

[Stijović, Rada i dr. (red.) Rečnik srpskohrvatskog književnog i narodnog jezika. IXIX. Beograd: SANU, 1959-2014]

Стошић, Љиљана. Библијске изреке и пословице. Нови Сад: Будућност, 2007.

[Stošić, Ljiljana. Biblijske izreke i poslovice. Novi Sad: Budućnost, 2007] 


\section{Kontrolné zdroje}

Biblia. Písmo Sväté Starej a Novej zmluvy. Liptovský Mikuláš: Tranoscius, 1978.

Biblia $<$ https://biblia.sk>29.09.2020.

Biblija $<$ http://biblija.biblija-govori.hr/> 29.09.2020.

Potúček, Juraj. Biblická konkordancia. Banská Bystrica: Slovenská biblická spoločnost', 1997.

БИБЛИЈА или Свето писмо Старога и Новог завјета / [превод Стари завјет Ђура Даничић, Нови завјет Комисија Светог архијерејског синода Српске православне цркве]. Београд: Библијско друштво Србије, 2012.

[BIBLIJA ili Sveto pismo Staroga i Novog zavjeta / [prevod Stari zavjet Đura Daničić, Novi zavjet Komisija Svetog arhijerejskog sinoda Srpske pravoslavne crkve]. Beograd: Biblijsko društvo Srbije, 2012]

Anna Margareta Lačok

\section{LEKSIČKI SASTAV I MOTIVACIJA BIBLIJSKIH FRAZEMA \\ (na primeru slovačke i srpske biblijske frazeologije)}

\section{Rezime}

Biblijski frazemi su definisani kao ustaljene jezičke jedinice povezane sa Biblijom. Prilikom njihovog istraživanja ipak nije dovoljno fokusirati se samo na jedinice koje u svom sastavu sadrže biblijski elemenat. Cilj našeg rada je pomoću izabranih primera slovačkih i srpskih frazema predstaviti njihov raznovrsni leksički sastav, ponuditi nekoliko grupa u koje ih možemo sa ovog aspekta svrstati i ukazati na njihovu karakteristiku i motivaciju. U pitanju su grupe koje sadrže: leksemu koja označava dobro ili zlo; osnovne hrišćanske principe; leksemu koja pokazuje na hrišćansku praksu; biblijski antroponim ili toponim. Posebnu grupu čine frazemi motivisani biblijskom pričom u čijem sastavu se nalaze lekseme religijskog i profanog karaktera, i frazemi koji se u Bibliji nalaze, no nisu nastali pod njenim uticajem, a u čijem sastavu nije biblijski, ni religijski elemenat. Frazemi u ovim grupama su motivisani različitim slikama, imaju različita značenja i ne sadrže uvek biblijsku, ni religijsku leksemu, na osnovu čega zaključujemo da je prilikom istraživanja biblijskih frazema neophodno osloniti se na mogućnost njihovog dokumentovanja citatima iz Svetog pisma.

Ključne reči: frazeologija, biblijska frazeologija, leksički sastav frazema, slovački jezik, srpski jezik. 